\title{
How Millennials and Generation $Z$ organise travel during the COVID-19 pandemic
}

\author{
Karolina Perčić ${ }^{1 *}$, Nada Spasić ${ }^{1}$ \\ ${ }^{1}$ Modern Business School, Belgrade, Serbia
}

\begin{abstract}
The subject of the paper is the consumer behaviour of Millennials and Generation $\mathrm{Z}$ as travellers in organising their travel. Through empirical research, conducted with online ques tionnaire in May 2021, the paper focuses on the way the above-mentioned generations in Serbia have organized travel (through a travel agency or on their own) before and during the COVID-19 pandemic, as well as the choice of accommodation during the pandemic, and the respondents' opinions on travel with COVID-19 passports. The aim of this paper is to discover the preferences and opinions of travellers when organizing travel under the new circumstances, as well as examining whether there are differences in the behaviour of Millennials and Generation $\mathrm{Z}$ as travellers before and during the pandemic, in order to provide significant information for the marketing decision making of touris mand hospitality organis ations. Almost a quarter of the world's population is made up of Millennials, who, along with Generation Z, make up the current and future force that contributes the most to the income generation. Members of this population in Serbia are less and less opting for the services of travel agencies, especially during the pandemic, while the number of pas sengers of these generations who organize self-directed travel is on the increase. Quantitative statis tical methods - descriptive statistics (frequency distribution) and comparative statis tics (Pears on $\chi 2$-test) were used for analys is of the obtained research results.
\end{abstract}

Keywords: Millennials, Generation Y, Generation Z, travel, pandemic JEL classification: M31

\section{Kako milenijalci i generacija $Z$ organizuju putovanja tokom COVID-19 pandemije}

Sažetak: Predmet rada je ponašanje potrošača, milenijalaca i generacije Z, kao turista u organizaciji putovanja. Putem empirijskog istraživanja, realizovanog tokom maja 2021. godine, razmatra se način organizacije putovanja (preko turističke agencije ili u sopstvenoj režiji) pomenutih generacija u Srbiji pre i tokom trajanja COVID-19 pandemije, kao i izbor vrste smeštaja tokom pandemije, i mišljenje ispitanika o putovanju uz COVID-19 pasoše. Cilj rada je dolaženje do saznanja koje su preferencije i mišljenja turista u vezi sa organizacijom putovanja pod novim okolnostima, kao i is pitivanje da li postoje razlike u ponašanju milenijalaca i generacije $\mathrm{Z}$ kao turista pre i tokom pandemije, kako bi se pružile

* karolina.percic@mbs.edu.rs

This article is an open access article distributed under the terms and conditions of the Creative Commons Attribution (CC BY) license (http://creativecommons.org/licenses/by/4.0/). 
značajne informacije za donošenje marketinških odluka turističkih i ugostiteljskih organizacija. Skoro četvrtinu svetske populacije čine milenijalci, koji uz generaciju $\mathrm{Z}$ predstavljaju trenutnuibuduću silu koja najviše, u odnosu na druge generacije, doprinosi ostvarivanju prihoda. Pripadnici ove populacije u Srbiji se sve manje odlučuju za usluge turis tičkih agencija, posebno tokompandemije, kada raste broj putnika ovih generacija koji organizuju putovanja u sopstvenoj režiji. Za analizu dobijenih rezultata istraživanja korišćene su kvantitativne statističke metode - deskriptivna statistika (distribucija frekvencija) i komparativna statistika (Pearson $\chi 2$-test).

Ključne reči: milenijalci, generacija $\mathrm{Y}$, generacija $\mathrm{Z}$, putovanje, pandemija JEL klasifikacija: M31

\section{Introduction}

Several significant crises - epidemics, the World Economic Crisis, political crises, natural disas ters have had a negative effect on the world tourism economy at the beginning of the 21st century. The most adverse effects until 2020 were caused by the World Economic Crisis, when indicators of touris $m$ development were unfavorable worldwide. However, regardles s of the type and duration of a crisis, tourism has shown an exceptional ability to recover (Milićević \& Ervaćanin, 2016) until the outbreak of the COVID-19 pandemic, the effects of which have not yet been fully seen as the crisis continues.

Org anis ations strive to understand and determine the reasons for certain consumer behaviour as it affects the success of business. During the COVID-19 pandemic, there have emerged numerous changes in consumer behaviour. In order to ensure survival on the market in unstable and uncertain business conditions, it is neces sary to conduct marketing research in a timely manner, among other business actions. The results of the research form a base for formulating an appropriate (marketing) strategy. Also, it is important for (marketing) managers in tourism to understand the behaviour of touris ts in order to formulate marketing and destination management strategies that are based on accurate knowledge of tourist behaviour and future trends (Senić \& Milojević, 2017).

The subject of the paper is the consumer behaviour of Millennials (als o called Generation Y) and Generation $\mathrm{Z}$ as travellers in organising their travel. Through empirical research, we have analyzed the way the Millennials and Gen Zedders in Serbia have org anised their travel (on their own or through a travel agency), before and during the COVID-19 pandemic, as well as their choice of accommodation during the pandemic, and the respondents' opinions on travel with COVID-19 passports. The aim of this paper is to discover the travellers' preferences and opinions when organising travel under the new circumstances, as well as to examine whether there are differences in the behaviour of Generation $\mathrm{Z}$ and Millennials as travellers before and during the pandemic, in order to provide important information for the process of making adequate marketing decisions of tourism and hospitality organis ations. The desktop and field research in the paper contributes to understanding the travel behaviour of Millennials and Generation Z, both in Serbia and worldwide, during the COVID-19 pandemic. The specificity of the work is reflected in the empirical research that refers to the respondents as members of Generation $\mathrm{Y}$ and Generation $\mathrm{Z}$ in Serbia, which contributes to understanding the way they organise their travel during the COVID-19 pandemic.

“The Millennials' generation is, in size, larger than any other adult cohort” (MSCI, 2020). In 2020, this generation made up 23\% of the world's population (United Nations, 2019). Millennials will represent $50 \%$ of international travellers by 2025 , and they "are already recognized by the tourism sector as a current and future driving force of revenues", (Hospitality net, 2015). Because of certain similarities, Millennials are often as sociated with 
Generation Z (ILTM, 2020), as suming that Gen Z have limited financial power because they are younger and mostly in the process of education. Millennials (born from 1980 to 1995) and Generation Z (born from 1995 to 2010) know best how to use the internet to plan and organise their travel.

\section{Trends in travel of younger generations}

It is a great challenge to offer products/services that are customized to consumers. Organis ations need to be aware of important trends prevailing among the target group in order to keep up with the changes and formulate adequate marketing strategies. It is also important for touris morg anis ations to know the characteris tics of their target group, as well as the latest trends of tourism consumers. The personality of travellers and the choice of destinations were the subject of research in the early seventies of the twentieth century (Plog, 1974), as well as the nature of tourism planning (Getz, 1986), which resulted in the formulation of models for application in tourism.

Some of the trends which emerged before the pandemic are the following ones: consumers are more aware of their needs and travellers are becoming more informed, more empowered and able to organise their travel independently; sustainable holidays; looking for a personal growth (meditation), us age of new technologies (Ortiz, 2019). Travellers increasingly value authenticity, destinations away frommajor tourist areas and options that reduce the negative impact on the environment. The most demanding tourists prefer to choose local places, looking for less crowded destinations or opt for large cities from which they visit smaller localplaces. The trend is tourism which focuses on rural locations where nature is dominant. There are touris mconsumers who opt for tourism products that include activities to seek disconnection and relax, like meditation and yoga. Some consumers grouped around the "Joy of Missing Out"(JOMO) like to be disconnected from their smartphones to enjoy their free time, and more travellers are looking for JOMO experiences (Euromonitor International, 2019). And when it comes to the use of technology, the usage of the Internet to search for tourist destinations and reserve accommodation is becoming more commonplace. Serbian consumers frequently use internet to book their travels, more when staying abroad than for domestic stays, and the most popular booking platform in Serbia are Booking.com and Airbnb (Kalinić \& Novaković, 2019).

According to a survey conducted by Booking.com (Donovan, 2021) on a sample of 20,934 respondents in 28 countries, during July 2020, travellers around the world (53\%) had a greater desire to explore the world in a more sustainable way. Travellers from Colombia (74\%), Brazil (71\%) and India (70\%) expres sed a particularly strong desire to become more environmentally oriented. More than half of travellers (63\%) intended to stay away from crowded touris tattractions; $51 \%$ of respondents will avoid travel during the season; and $48 \%$ of respondents will visit alternative destinations to prevent overcrowding. According to the next survey of the same company (Booking.com) on a sample of 29,349 respondents in 30 countries, during March 2021, 68\% of travellers wanted the money they spent on travel to go to the local community; and $84 \%$ of passengers planned to reduce the waste and recycle plastic products when visiting a particular destination, and this percentage was growing among travellers from Thailand (94\%), Croatia (91\%) and Argentina (90\%). Temporary sus pension of travel had ins pired $83 \%$ of travellers to make sustainable travel their priority in the future, while $70 \%$ of respondents were more likely to choose accommodation that applies sustainable practices. These data, in addition to revealing the motivations of passengers after the pandemic, also emphasize the importance of taking further steps to improve the sustainability of tourism and hos pitality facilities. 
Millennials are "the first generation that experience the technological boom", and "they are the most readily involved in the world of social media influence" (ETC, 2016). According to ETC (2016), the following characteristics also apply to Millennials. Generation Y like to show off their trip online and they also like to stay in the most luxurious destinations they can afford. "Millennials love to travel, but not just for leisure. They prioritize adventure, learning about the world and discovering new places". Millennials and Gen Z know better than other (older) generations how to use the internet to plan and organise their travel. CBI Ministry of Foreign Affairs (2021) has stated the following characteristics of Millennials. They value green business practices, and "do not look for quality only, but for premium personalised service for a reas onable price". Generation Yexplore on the go to find the best traveloptions for themselves, and travel more often with friends, colleagues and relatives than other generations. It is characteristic of the millennial market that the share of female travellers is above average.

According to the Deloitte Global Millennial Survey (Deloitte, 2019, p. 5), 57\% of Millennials and GenerationZ reported that "travel the world was their number one ambition, even overtaking high earning, owning a home and having children". Compared to previous generations, the life stage without family commitments has been shifted to older ages and this has resulted in consequences related to other dimensions of life: the pattern of savings, consumption and travel (MSCI, 2020). The Millennial generation is more likely than other age brackets (Gen $\mathrm{X}$ and Boomers) to consider returning to travel again after lifting the lockdowns and they are less risk-averse (ILTM, 2020).

\section{The impact of the COVID-19 pandemic on Millennials and Generation $\mathrm{Z}$ travellers}

The COVID-19 pandemic and its resulting recession will have a long-lasting impact on younger generations - Generation Yand Generation Z. Their consumer behaviour is largely shaped by the following factors: increasing stress, home-oriented lives and rising unemployment. According to Environics Institute research (Environics Institute, 2021), a majority of Canada's younger generations (aged 18-40) say that the COVID-19 pandemic has had at least a moderate impact on their lives, and most expect their lives to return to normal after the pandemic in a period of seven months to two years. Organisations need to adapt their (marketing) strategies in order to stay relevant to Millennials and Generation Z during the pandemic and beyond (Euromonitor International, 2020).

According to a study by Advantage (2020), 44\% of Millennial travellers (25-34 years old; from UK) "who do not currently book through a travel agent would use one in future, indicating advice, expertise and the reas surance of having someone to help if travel plans need to change, as the main reasons for now favoring a human travel agent over booking online". The 18-24 age group (76\%) has demonstrated that the younger audience is open to booking with their local travel agent. The results als ofound that, the younger the age group, the more willing they are to pay for a COVID test to travel. $79 \%$ of $18-24$ age group have confirmed they would pay for a test to travel, whilst $56 \%$ of respondents over 65 years old would not be prepared to do so.

During the crisis, there is an above average level of hoperelative to the state of travel (DCI, 2020). Across all generations (GenerationZ, Generation Y - Millennials, Generation X and Boomers) in the USA and Canada, "people are neither hopeless nor extremely hopeful, but somewhere in the middle" (DCI, 2020). Millennials have said that they will travelduring the pandemic, engaging in riskier behaviour than older generations. Generation X and Boomers have stated that they are less afraid of COVID-19 than Millennials and Generation Z. It is common for all generations in terms of future travel that they are the least afraid to travel to 82 
domes tic locations, but going abroad creates the greatest concern. The youngest generation (Gen $\mathrm{Z}$ ) are engaging in riskier travel than the older generations, but the results also indicate that Gen Z has planned the least travel in 2020.

According to the same survey (DCI, 2020), the greatest percentage of Generation Z are afraid of getting sick during/after travel (20\%), then, Gen $\mathrm{Z}$ are afraid of being quarantined when they return home (16\%), of flights cancelling (12\%), of being stuck in the destination $(12 \%)$, of getting denied access to a region/crossing borders (12\%), attractions/restaurants being closed $(8 \%)$, transmitting the virus $(8 \%)$. Millennials are afraid of getting sick during/after travel (17\%), transmitting the virus (16\%), being stuck in the destination $(15 \%)$, being quarantined when they return home (13\%), flights cancelling (13\%), of getting denied access to a region/crossing borders ( $9 \%$ ). The youngest generation (Generation Z) said they would be willing to pay more money to travel somewhere without coronavirus threats $(58 \%)$, and one quarter of Millennials $(25 \%)$ would be willing to pay more for coronavirus-free destinations.

"The challenge for the touris mindustry would be to bring back tourists' travel confidence by introducing measures that ensure their safety against the present health crisis" (Seabra et al., 2021, p. 479). During the pandemic, tourists have asked questions about the hygiene conditions of the traveldestinations, and they are looking for clarity regarding emergency services from touris mindustry that are beyond the services and hospitality they are offering. Therefore, the managers of tourism organizations may be required to work with the government at the local and national levels to solve problems affecting the tourism industry due to new requirements regarding COVID-19 (Seabra et al., 2021).

Before COVID-19, Millennials travelled more than any other generation per year (an average is 35 days per year), and $83 \%$ of Millennials worldwide chose to vacation at all-inclusive resorts where they had every thing they needed (Rezdy, 2018). "Many Millennials are already engaging with luxury travel in ways unexpected of them", and they are very important in helping the luxury travel industry recover (ILTM, 2020).

According to Rezdy (2018), more than $72 \%$ of Millennial travellers said that a solid advertising promotion could convince them to book travel arrangements, therefore, "online advertising, including retargeting and other social strategies, is the best way to connect and engage with Millennials". Amid the pandemic, consumer habits have changed and an effective presence on social media has become very important. Touris $m$ and hospitality organisations should engage with influencers on social media and operate across multichannel platforms to ensure a stronger position for recovery. During the COVID-19 pandemic, YouTube and Twitter have topped the list of widely-used platforms for travel promotions, but TikTok also holds marketing potential (GlobalData, 2020).

Based on the review of previous literature on the topic (Adv antage, 2020; DCI, 2020; ILTM, 2020; Rezdy, 2018; Seabra et al., 2021) and the authors' assumptions, the following research hypotheses were defined:

Research hypothesis H1: There is a statistically significant difference in the respondents' ans wers (according to gender, generations, the amount of income) in relation to the question regarding the organisation of travel (under their own direction, through a travel agency) before the outbreak of the pandemic.

Research hypothesis H2: There is a statistically significant difference in the respondents' ans wers (according to gender, generations, the amount of income) in relation to the question regarding the organisation of travel (on their own, through a travel agency) during the pandemic. 
Research hypothesis H3: There is a statistically significant difference in the respondents' ans wers (according to gender, generations, the amount of income) in relation to the choice of accommodation facilities during the pandemic (private accommodation for personal hygiene care, checked hotels, any accommodation).

Research hypothesis H4: There is a statistically significant difference in the respondents' ans wers (according to gender, generations, the amount of income) in relation to the question regarding the opinion about travel with the COVID-19 pass port.

Research hypothesis H5: There is a statistically significant difference in the answers of Millennials and Generation $\mathrm{Z}$ as travellers before and during the pandemic.

\section{Methodology of the empirical research}

The quantitative, survey research was conducted by questionnaire in written form. The online survey was prepared specially for the needs of this research and was distributed to respondents aged 20 to 40 (to members of Generation $\mathrm{Y}$ - Millennials and Generation Z), in the period from 9th May to 21st May, 2021. Respondents from all regions of Serbia were included. The intentions of consumers as travellers regarding their travel org anisation during the pandemic were examined.

The sample is stratified and consis ts of 300 respondents: 150 respondents of Generation $\mathrm{Z}$ (aged 20 to 26) and 150 respondents of Generation Y (aged 27 to 40). Older members of Generation $\mathrm{Z}$, who can make travel decisions and travel independently, were taken into account. The structure of the sample according to gender is as follows: $50 \%$ of male respondents, $50 \%$ female; according to the employment status: student (36\%), employed $(51 \%)$ and unemployed (13\%); and according to the amount of monthly income during the pandemic (taking into account those who earn an income): $20 \%$ of respondents with below average income, $69 \%$ of respondents with average income and $11 \%$ of respondents with above average income. The statistical error of the sample is $5.6 \%$. Due to the insufficient number of respondents for reliable representativeness, this research represents a case study.

The SPSS was used for data processing and analysis, as well as for the interpretation of the obtained res earch results. From the quantitative statistical methods, the following were used: descriptive statis tics (frequency dis tribution) and comparative statistics (Pears on $\chi 2$-test).

\section{Results of the empirical research}

Nearly half of Generation Y and Generation Z respondents (47\%) would choose countries that abide by all epidemiological measures and where they would feel safe. Most respondents $(45 \%)$ do not care where they would stay in the future, while $22 \%$ would choose only verified hotels in terms of implementing epidemiological measures, $11 \%$ would opt for private accommodation where they would themselves be in charge of hygiene, and $22 \%$ are undecided on this is sue. According to $\chi 2$-test (Value $=94.404^{\mathrm{a}}, \mathrm{df}=3, \mathrm{p}=0.00<0.05$ ), it was found that there is a statistically significant difference in the responses of respondents according to gender in relation to the question regarding the choice of accommodation facilities in the future (Table 1). There is a higher percentage of female respondents whose choice would be private accommodation where they would themselves be in charge of hygiene (19\%) compared to male respondents $(2 \%)$, and there is a higher percentage of male respondents who would choose verified hotels (38\%) compared to female respondents $(7 \%)$, (Table 4). According to $\chi 2$-test (Value $=24.069^{\mathrm{a}}, \mathrm{df}=3, \mathrm{p}=0.00<0.05$ ), it was found that there is a statis tically significant difference in the res ponses of the respondents according to 
generations in relation to the choice of accommodation facilities in the future (Table 2). The percentage of Millennials whose choice would be private accommodation for hygiene reasons $(15 \%)$ and verified hotels $(27 \%)$ is higher compared to the Generation $\mathrm{Z}$ (private accommodation: $6 \%$, hotels: $18 \%$ ), a higher percentage of whom point out that they do not care where they would stay (59\%) compared to Millennials (31\%), (Table 5). According to Table 3, there is a statistically significant difference in the responses of respondents according to the amount of income in relation to the choice of facilities for accommodation $\left(\chi 2\right.$-test, Value $\left.=35.239^{\mathrm{a}}, \mathrm{df}=6, \mathrm{p}=0.00<0.05\right)$. The largest percentage of res pondents with incomes at the average (45\%) and above the average (54\%) said that they do not care where they would stay (Table 6). $16 \%$ of respondents with below-average incomes and $10 \%$ of respondents with average incomes would choose private accommodation where they would themselves be in charge of hygiene. Verified hotels would be chosen by $12 \%$ of respondents with below-average incomes, $30 \%$ of respondents with average incomes and $32 \%$ of respondents with above-average incomes.

Table 1: Testing a statistically significant difference in the answers of the respondents according to gender in relation to the stated questions $(\chi 2$-test)

\begin{tabular}{|l|c|c|c|}
\hline Questions in the questionnaire & Value & Df & P \\
\hline $\begin{array}{l}\text { Before the outbreak of the pandemic, I organised my } \\
\text { travel: through a travel agency, on my own }\end{array}$ & $0.230^{\mathrm{a}}$ & 1 & 0.632 \\
\hline $\begin{array}{l}\text { During the pandemic, I have organised my travel: } \\
\text { through a travel agency, on my own }\end{array}$ & $6.839^{\mathrm{a}}$ & 1 & $0.009^{*}$ \\
\hline $\begin{array}{l}\text { In the future, I will choose accommodation: exclusively } \\
\text { in verified hotels, private accommodation where I } \\
\text { would my self be in charge of hygiene, Idon't care } \\
\text { where I will be accommodated, I'm not sure }\end{array}$ & $94.404^{\mathrm{a}}$ & 3 & $0.00^{*}$ \\
\hline $\begin{array}{l}\text { Do you think that people should travelonly with } \\
\text { COVID-19 pas sports? Yes, because safety comes first; } \\
\text { No, I do not think so; I'mnot sure }\end{array}$ & $42.222^{\mathrm{a}}$ & 2 & $0.00^{*}$ \\
\hline
\end{tabular}

Notes: $* p<0.05$

Source: Author's research

Table 2: Testing a statistically significant difference in the answers of the respondents according to generations in relation to the stated questions in questionnaire ( $\chi 2$-test)

\begin{tabular}{|l|c|c|c|}
\hline Ques tions & Value & Df & P \\
\hline $\begin{array}{l}\text { Before the outbreak of the pandemic, I organised my } \\
\text { travel: through a travel agency, on my own }\end{array}$ & $0.919^{\mathrm{a}}$ & 1 & 0.338 \\
\hline $\begin{array}{l}\text { During the pandemic, Ihave organised my travel: } \\
\text { through a travel agency, on my own }\end{array}$ & $6.840^{\mathrm{a}}$ & 1 & $0.009^{*}$ \\
\hline $\begin{array}{l}\text { In the future, Iwill choose accommodation: exclusively } \\
\text { in verified hotels, private accommodation where I } \\
\text { would my self be in charge of hygiene, Idon't care } \\
\text { where I will be accommodated, I'm not sure }\end{array}$ & $24.069^{\mathrm{a}}$ & 3 & $0.00^{*}$ \\
\hline $\begin{array}{l}\text { Do you think that people should travelonly with } \\
\text { COVID-19 pas sports? Yes, because safety comes first; } \\
\text { No, I do not think so; I'mnot sure }\end{array}$ & $8.495^{\mathrm{a}}$ & 2 & $0.0014^{*}$ \\
\hline
\end{tabular}

Notes: $* \mathrm{p}<0.05$

Source: Author's research 
Table 3: Testing a statistically significant difference in the answers of the respondents according to the amount of income in relation to the stated questions $(\chi 2$-test)

\begin{tabular}{|l|c|c|c|}
\hline Questions & Value & df & P \\
\hline $\begin{array}{l}\text { Before the outbreak of the pandemic, I organised my } \\
\text { travel: through a travel agency, on my own }\end{array}$ & $11.661^{\mathrm{a}}$ & 2 & $0.003^{*}$ \\
\hline $\begin{array}{l}\text { During the pandemic, I have organised my travel: } \\
\text { through a travel agency, on my own }\end{array}$ & $11.991^{\mathrm{a}}$ & 2 & $0.002^{*}$ \\
\hline $\begin{array}{l}\text { In the future, Iwill choose accommodation: exclusively } \\
\text { in verified hotels, private accommodation where I } \\
\text { would my self be in charge ofhygiene, I don't care } \\
\text { where I will be accommodated, I'm not sure }\end{array}$ & $35.239^{\mathrm{a}}$ & 6 & $0.00^{*}$ \\
\hline $\begin{array}{l}\text { Do you think that people should travelonly with } \\
\text { COVID-19 pas sports? Yes, because safety comes first; } \\
\text { No, I do not think so; I'mnot sure }\end{array}$ & $32.970^{\mathrm{a}}$ & 4 & $0.00^{*}$ \\
\hline
\end{tabular}

Notes: $* \mathrm{p}<0.05$

Source: Author's research

Regarding the organisation of travel, before the outbreak of the pandemic, $63 \%$ of Generation Y and Generation Z respondents org anised travel on their own, and 37\% through a travel agency, while during the pandemic, $81 \%$ of those who travelled org anised the travel on their own, and $19 \%$ through a travel agency. According to $\chi 2$-test (Value $=0.230^{\mathrm{a}}, \mathrm{df}=1$, $p=0.632>0.05)$, it was found that there is no statistically significant difference in the ans wers of res pondents according to gender in relation to the travel organis ation before the pandemic (Table 1), that is, the percentage of the male and female respondents who organised self-directed travel (male: 62\%, female: 65\%) and through travel agencies (male: $38 \%$, female: $35 \%$ ) is approximate. On the other hand, when observing those who travelled during the pandemic, it was found that there is a statistically significant difference in the responses according to gender in relation to the organisation of travel during the pandemic $\left(\chi 2\right.$-test, Value $\left.=6.839^{\mathrm{a}}, \mathrm{df}=1, \mathrm{p}=0.009<0.05\right)$, i.e. there is a higher percentage of female respondents who organise self-directed travel $(89 \%)$ in relation to the services of travel agencies, and in relation to male respondents (75\%), (Table 4$)$. 
Table 4: Distribution of respondents by gender and questions

\begin{tabular}{|c|c|c|c|c|}
\hline \multirow{2}{*}{ Questions in the questionnaire } & \multicolumn{2}{|c|}{ Gender } & \multirow{2}{*}{$\mathbf{N}$} & \multirow{2}{*}{$\%$} \\
\hline & Male & Female & & \\
\hline \multicolumn{5}{|l|}{$\begin{array}{l}\text { Before the outbreak of the pandemic, I } \\
\text { organis ed my travel: }\end{array}$} \\
\hline through a travel agency & $57(38 \%)$ & $53(35 \%)$ & \multirow{2}{*}{300} & 37 \\
\hline on my own & $93(62 \%)$ & $97(65 \%)$ & & 63 \\
\hline $\mathrm{N}(\%)$ & $150(100 \%)$ & $150(100 \%)$ & & \\
\hline \multicolumn{5}{|c|}{ During the pandemic, I have organised my travel: } \\
\hline through a travel agency & $33(25 \%)$ & $10(11 \%)$ & \multirow{2}{*}{225} & 19 \\
\hline On my own & $100(75 \%)$ & $82(89 \%)$ & & 81 \\
\hline $\mathrm{N}(\%)$ & $133(100 \%)$ & $92(100 \%)$ & & \\
\hline \multicolumn{5}{|l|}{ In the future, I will choose accommodation: } \\
\hline exclusively in verified hotels & $57(38 \%)$ & $10(7 \%)$ & \multirow{4}{*}{300} & 22 \\
\hline $\begin{array}{l}\text { private accommodation where I would } \\
\text { myself be in charge of hygiene }\end{array}$ & $3(2 \%)$ & $29(19 \%)$ & & 11 \\
\hline I don't care where I will be accommodated & $81(54 \%)$ & $54(36 \%)$ & & 45 \\
\hline I'm not sure & $9(6 \%)$ & $57(38 \%)$ & & 22 \\
\hline $\mathrm{N}(\%)$ & $150(100 \%)$ & $150(100 \%)$ & & \\
\hline \multicolumn{5}{|c|}{ Do you think that people should travel only with COVID-19 pas sports? } \\
\hline Yes, becau se safety comes first & $56(37 \%)$ & $11(7 \%)$ & \multirow{3}{*}{300} & 22 \\
\hline No, I do not thinkso & $74(49 \%)$ & $122(81 \%)$ & & 65 \\
\hline I'm not sure & $20(14 \%)$ & $17(12 \%)$ & & 13 \\
\hline $\mathrm{N}(\%)$ & $150(100 \%)$ & $150(100 \%)$ & & \\
\hline
\end{tabular}

Source: Author's research

According to $\chi 2$-test $\left(\right.$ Value $\left.=0.919^{\mathrm{a}}, \mathrm{df}=1, \mathrm{p}=0.338>0.05\right)$, it was found that there is no statis tically significant difference in the responses of the respondents according to their age group in relation to the question regarding the organis ation of travel before the pandemic (Table 2). The percentage of the members of Generation $Z$ and Generation $Y$ who organised travel both on their own (Z: 61\%, Y: 66\%) and through travel agencies (Z: 39\%, Y: 34\%) before the pandemic is approximate. When taking into account those who reported travel during the pandemic, there is a statistically significant difference in the respondents' responses according to their age group in relation to the organis ation of travel during the 
Perčić, K., Spasić, N. - How Millennials and Generation Z organise travel during the COVID-19 pandemic - Hotel and Tourism Management, 2021, Vol. 9, No. 2: 79-94.

pandemic $\left(\chi 2\right.$-test, Value $\left.=6.840^{\mathrm{a}}, \mathrm{df}=1, \mathrm{p}=0.009<0.05\right)$, i.e. there is a higher percentage of Generation $\mathrm{Z}$ members who have organised self-directed travel (88\%) compared to the services of travel agencies $(12 \%)$, and in relation to members of Generation Y who have organised travel on their own (75\%), (Table 5).

Table 5: Distribution of respondents by age group and questions in the questionnaire

\begin{tabular}{|c|c|c|c|}
\hline \multirow{2}{*}{ Questions in the questionnaire } & \multicolumn{2}{|c|}{ Generation } & \multirow{2}{*}{$\mathbf{N}$} \\
\hline & $\mathbf{Z}$ & $\mathbf{Y}$ & \\
\hline \multicolumn{4}{|l|}{$\begin{array}{l}\text { Before the outbreak of the pandemic, I } \\
\text { organised my travel: }\end{array}$} \\
\hline through a travel agency & $59(39 \%)$ & $51(34 \%)$ & \multirow{2}{*}{300} \\
\hline On my own & $91(61 \%)$ & $99(66 \%)$ & \\
\hline $\mathrm{N}(\%)$ & $150(100 \%)$ & $150(100 \%)$ & \\
\hline \multicolumn{4}{|l|}{ During the pandemic, Ihave organis ed my travel: } \\
\hline through a travel agency & $12(12 \%)$ & $31(25 \%)$ & \multirow{2}{*}{225} \\
\hline On my own & $91(88 \%)$ & $91(75 \%)$ & \\
\hline $\mathrm{N}(\%)$ & $150(100 \%)$ & $150(100 \%)$ & \\
\hline \multicolumn{4}{|l|}{ In the future, I will choose accommodation: } \\
\hline exclusively in verified hotels & $27(18 \%)$ & $40(27 \%)$ & \multirow{4}{*}{300} \\
\hline $\begin{array}{l}\text { private accommodation where I would myself } \\
\text { be in charge of hygiene }\end{array}$ & $9(6 \%)$ & $23(15 \%)$ & \\
\hline I don't care where I will be accommodated & $88(59 \%)$ & $47(31 \%)$ & \\
\hline I'm not sure & $26(17 \%)$ & $40(27 \%)$ & \\
\hline $\mathrm{N}(\%)$ & $150(100 \%)$ & $150(100 \%)$ & \\
\hline \multicolumn{4}{|l|}{$\begin{array}{l}\text { Do you think that people should travel only with } \\
\text { COVID-19 passports? }\end{array}$} \\
\hline Yes, because safety comes first & $31(21 \%)$ & $36(24 \%)$ & \multirow{3}{*}{300} \\
\hline No, I do not think so & $108(72 \%)$ & $88(59 \%)$ & \\
\hline I'm not sure & $11(7 \%)$ & $26(17 \%)$ & \\
\hline $\mathrm{N}(\%)$ & $150(100 \%)$ & $150(100 \%)$ & \\
\hline
\end{tabular}

Source: Author's research

When considering the distribution of the respondents according to the amount of income in relation to the org anisation of travel before the outbreak of the pandemic (Table 3), there is a statis tically significant difference in the respondents' res ponses $\left(\chi 2\right.$-test, Value $=11.661^{\mathrm{a}}, \mathrm{df}$ $=2, p=0.003<0.05)$, i.e. $69 \%$ of respondents with an average income organis ed travel 88 
under their own direction in relation to the services of travel agencies (31\%), and $46 \%$ of respondents with below average and above average incomes organis ed self-directed travel (and 54\% through travel agencies), (Table 6). When observing the distribution of respondents according to the level of income in relation to travel organisation during the pandemic, there is a statistically significant difference in the answers of res pondents $(\chi 2$-test, Value $=11.991 \mathrm{a}, \mathrm{df}=2, \mathrm{p}=0.002<0.05)$, that is, $87 \%$ of respondents with average incomes have organised self-directed travel during the pandemic (and 13\% through travel agencies), as well as $85 \%$ of respondents with below-average incomes (and 15\% through travel agencies) and $57 \%$ of respondents with above-average incomes (and $43 \%$ through travel agencies), (Table 6).

Table 6: Dis tribution of res pondents by amount of income and questions in the questionnaire

\begin{tabular}{|c|c|c|c|c|}
\hline \multirow[b]{2}{*}{ Questions in the questionnaire } & \multicolumn{3}{|c|}{ Amount of income } & \multirow[b]{2}{*}{$\mathbf{N}$} \\
\hline & $\begin{array}{c}\text { Below } \\
\text { average }\end{array}$ & Average & $\begin{array}{c}\text { Above } \\
\text { average }\end{array}$ & \\
\hline \multicolumn{5}{|l|}{$\begin{array}{l}\text { Before the outbreak of the pandemic, } \\
\text { I organis ed my travel: }\end{array}$} \\
\hline through a travel agency & $27(54 \%)$ & $54(31 \%)$ & $15(54 \%)$ & \multirow{2}{*}{251} \\
\hline On my own & $23(46 \%)$ & $119(69 \%)$ & $13(46 \%)$ & \\
\hline $\mathrm{N}(\%)$ & $50(100 \%)$ & $173(100 \%)$ & $28(100 \%)$ & \\
\hline \multicolumn{5}{|l|}{$\begin{array}{l}\text { During the pandemic, Ihave organised my } \\
\text { travel: }\end{array}$} \\
\hline through a travel agency & $3(15 \%)$ & $19(13 \%)$ & $9(43 \%)$ & \multirow{2}{*}{188} \\
\hline on my own & $17(85 \%)$ & $128(87 \%)$ & $12(57 \%)$ & \\
\hline $\mathrm{N}(\%)$ & $20(100 \%)$ & $147(100 \%)$ & $21(100 \%)$ & \\
\hline \multicolumn{5}{|l|}{$\begin{array}{l}\text { In the future, I will choose } \\
\text { accommodation: }\end{array}$} \\
\hline exclusively in verified hotels & $6(12 \%)$ & $52(30 \%)$ & $9(32 \%)$ & \multirow{4}{*}{251} \\
\hline $\begin{array}{l}\text { private accommodation where I would } \\
\text { myself be in charge of hygiene }\end{array}$ & $8(16 \%)$ & $17(10 \%)$ & $0(0 \%)$ & \\
\hline $\begin{array}{l}\text { I don't care where I will be } \\
\text { accommodated }\end{array}$ & $12(24 \%)$ & $78(45 \%)$ & $15(54 \%)$ & \\
\hline I'm not sure & $24(48 \%)$ & $26(15 \%)$ & $4(14 \%)$ & \\
\hline $\mathrm{N}(\%)$ & $50(100 \%)$ & $173(100 \%)$ & $28(100 \%)$ & \\
\hline \multicolumn{5}{|l|}{$\begin{array}{l}\text { Do you think that people should travel } \\
\text { only with COVID-19 pas s ports? }\end{array}$} \\
\hline Yes, because safety comes first & $6(12 \%)$ & $34(20 \%)$ & $18(64 \%)$ & 251 \\
\hline
\end{tabular}


Perčić, K., Spasić, N. - How Millennials and Generation Z organise travel during the COVID-19 pandemic - Hotel and Tourism Management, 2021, Vol. 9, No. 2: 79-94.

\begin{tabular}{|c|c|c|c|}
\hline No, I do not think so & $35(70 \%)$ & $117(68 \%)$ & $10(36 \%)$ \\
\hline I'm not sure & $9(18 \%)$ & $22(12 \%)$ & $0(0 \%)$ \\
\hline $\mathrm{N}(\%)$ & $50(100 \%)$ & $173(100 \%)$ & $28(100 \%)$ \\
\hline
\end{tabular}

Source: Author's research

As for the attitude of passengers regarding COVID-19 pas sports, $65 \%$ believe that they are not necessary for travel; $22 \%$ think that this type of passport is needed, and $13 \%$ are undecided on this issue. According to Table 4, there is a higher percentage of male respondents who consider it necessary to travel with a COVID-19 passport (37\%) compared to female respondents (7\%). There is a statistically significant difference in the answers of the respondents according togender in relation to this question $\left(\chi 2\right.$-test, Value $=42.222^{\mathrm{a}}, \mathrm{df}$ $=2, \mathrm{p}=0.00<0.05$ ) (Table 1). Also, there is a statistically significant difference in the ans wers of the respondents according to generations in relation to this question ( $\chi 2$-test, Value $\left.=8.495^{\mathrm{a}}, \mathrm{df}=2, \mathrm{p}=0.0014<0.05\right)$ (Table 2), i.e. members of Generation $\mathrm{Z}$ in a higher percentage consider that this type of passport is not necessary $(72 \%)$ in relation to members of Generation Y (59\%), (Table 5). It was also found that there is a statistically significant difference in the answers of the res pondents according to the amount of income in relation to the same question $\left(\chi 2\right.$-test, Value $\left.=32.970^{\mathrm{a}}, \mathrm{df}=4, \mathrm{p}=0.00<0.05\right)($ Table 3$)$. $12 \%$ of respondents with a below-average income, $20 \%$ of respondents with an average income, and $64 \%$ of respondents with an above-average income believe that a COVID-19 passport is necessary for security reasons.

\section{Conclusion}

The COVID-19 pandemic is affecting everyone across the planet. The majority of people have adapted their lives to the pandemic and live their lives according to the proscribed "rules". Consumer behaviour in touris mhas als o changed. Bus inesses around the world have been adapting to the changing needs and expectations of Millennials and Generation $\mathrm{Z}$ in the light of COVID-19 (Euromonitor International, 2020). The pandemic has also affected the consumers psychologically - they choose "safer" offers, opt for things that they can control to some extent, such as, for example, self-directed travel, where they will org anise the whole travel and stay at a certain place and type of accommodation.

Based on the examined behaviour of consumers of tourist services - the members of Generation Y and Generation Z in Serbia, it can be concluded that they are less opting for the services of travel agencies in org anising their travel, es pecially in the new condition s dictated by the COVID-19 pandemic. During the pandemic, the number of pas sengers who have organised travel under their own direction has increased (63\% of respondents before the outbreak of the pandemic; $81 \%$ during the pandemic). Thus, the demand for travel arrangements through travel agencies has decreased during the pandemic. A larger percentage of the members of Generation $\mathrm{Z}$ and Millennials have decided to org anise selfdirected travel in relation to the services of travel agencies, both before and during the pandemic. There is a higher percentage of Generation $\mathrm{Z}$ who have organis ed self-directed travel during the pandemic (88\%) compared to Millennials (75\%), and a higher percentage of Millennials who use travel agency services (25\%) compared to Generation Z (12\%). There is a higher percentage of female respondents who organise travel on their own (89\%) compared to male res pondents (75\%). During the pandemic, the highest percentage of respondents with average income have organised self-directed travel (87\%) compared to the below-average 
income earners $(85 \%)$ and above-average income earners $(57 \%)$. The percentage of the respondents with above-average income who use the services of a travel agency is higher (43\%) compared to other categories with a lower income (below average: $15 \%$; average amount of income: $13 \%$ ). The results of the research show that there is a statistically significant difference in the respondents' responses according to gender, age group and the amount of income in relation to organisation of travel (under their own direction, through a travelagency) during the pandemic, while it is proven that there is no statistically significant difference in the respondents' responses by gender and age group in relation to travel organis ation before the outbreak of the pandemic. There is only a statistically significant difference in the respondents' responses according to the amount of income before the pandemic. Hence, the research hypothesis $H_{1}$ is partially confirmed and hypothesis $\mathrm{H}_{2}$ is fully confirmed.

As it has been determined that there is a statistically significant difference in the respondents' responses according to gender, age group and income in relation to the choice of accommodation (private accommodation where they would themselves be in charge of hy giene, verified hotels, any accommodation) while travelling during the pandemic, research hypothesis $\mathrm{H}_{3}$ has been confirmed. There is a higher percentage of female respondents whose choice would be to book private accommodation where they would themselves be in charge of hygiene (19\%) compared to male respondents $(2 \%)$, while male respondents prefer verified hotels (38\%) compared to female respondents (7\%). Generation $\mathrm{Z}$ members would choose private accommodation for hygiene reasons in a smaller percentage $(6 \%)$, as well as verified hotels (18\%) compared to Millennials (private accommodation: $15 \%$, hotels: $27 \%$ ). Also, Generation $\mathrm{Z}$ points out that they do not care where they stay in a higher percentage (59\%) compared to Generation $\mathrm{Y}(31 \%)$. The highest percentage of private accommodation would be chosen by respondents with incomes below average, and the verified hotels would be chosen by respondents with above-average incomes.

It is proven that there is a statistically significant difference in respondents' responses according to gender, age group and the amount of income in relation to the opinion about travel with the COVID-19 passport, and research hypothesis $H_{4}$ has been confirmed. There is a higher percentage of male res pondents who consider it neces sary to travel with a COVID19 passport (37\%) compared to female respondents (7\%). A higher percentage of members of Generation $\mathrm{Z}$ consider that this type of passport is not necessary $(72 \%)$ in relation to members of Generation Y (59\%). $12 \%$ of res pondents with a below-average income, $20 \%$ of respondents with an average income and $64 \%$ of res pondents with an above-average income believe that COVID-19 pas s port is necessary for security reasons. $65 \%$ of these generations believe that this passport isn't necessary for travel and $22 \%$ believe that it is needed.

The research hypothesis $\mathrm{H} 5$ is mostly confirmed as it has been determined that there is a statistically significant difference in the answers of Generation $\mathrm{Z}$ and Millennials as travellers in relation to the choice of accommodation facilities in the future, than in relation to organisation of travel during the pandemic, as well as in relation to the question regarding the opinion about travel with the COVID-19 pas sport. The results of the research show that there is no statistically significant difference in the responses of these generations in relation to the organisation of travel before the pandemic. During the pandemic, there is a higher percentage of Generation $\mathrm{Z}$ members who have organised self-directed travel (88\%) in relation to members of Generation Y $(75 \%)$. Also, members of Generation Z consider that the COVID-19 pas sport is not necessary for travel in a higher percentage (72\%) compared to members of Generation Y (59\%). A higher percentage of Generation Y has stated that they choose private accommodation for hygiene reasons $(15 \%)$ and verified hotels $(27 \%)$ compared to Generation $\mathrm{Z}$ (private accommodation: 6\%, hotels: $18 \%$ ). 
The global travel industry had one of the strongest expansion cycles in its history prior to the pandemic. It is believed that the Millennials will offer the industry a lifeline during the recovery (Gas dia \& Jackson, 2020). "With or without a cris is, Gen Z and Millennials are of special interest, given their increasing spending power in the coming years and their ability to influence older generations" (Bona et al., 2020).

Practical implication. Given that there is a decrease in opting for the services of travel agencies, especially during the pandemic, among Generation $\mathrm{Z}$ and Millennials in Serbia, touris mand hospitality org anisations need to be creative in order to attract members of these generations. Managers of tourismand hospitality org anisations should take care of the image of the des tination taking into account health, safety and hygiene requirements. They need to use social media like YouTube, Twitter, TikTok, Instagram, and travel influencers to attract travellers. Upon the completion of travel, organisations need to continue maintaining contact with their customers through their social networks. Marketing managers should also keep in mind that, while Millennial travellers have money to spend, they still like to have a great deal. "Approximately 92\% of Millennials report that they won't finalize their booking until they feel they have the best deal possible" (Rezdy, 2018).

Limitations and recommendations for the future research. The paper provides mainly factual ans wers to the questions regarding the organisation of travel by Millennials and Generation $\mathrm{Z}$, without taking into consideration the motives for certain consumer behaviours of tourists during the COVID-19 pandemic, which may be a direction of some future research as an upgrade of the presented analyses in this work. This research represents a case study, as the sample consis ts of an insufficient number of respondents for reliable representativeness, so research on the same topic can be repeated with a larger number of respondents in Serbia.

\section{Conflict of interest}

The authors declare no conflict of interest.

\section{References}

1. Advantage. (2020, October 22). Coronavirus travel research: $44 \%$ of Millennials would book with a travel agent in the future. Retrieved April 29, 2021 from https://www.advantagemembers .com/news -listing/coronavirus-travel-res earch-booktravel-agent.html

2. Bona, C., Koslow, L., Frantz, R., Nadres, B., \& Ratajczak, D. (2020, June 16). How marketers can win with Gen Z and Millennials post-COVID-19. Retrieved April 28, 2021 from https://www.bcg.com/en-gb/publications/2020/how-marketers-can-win-withgen-z-millennials-post-covid

3. CBI - Ministry of Foreign Affairs. (2021, January 20). The European market potential for Generation Y tourism. Retrieved April 29, 2021 from https://www.cbi.eu/marketinformation/touris $\mathrm{m} / \mathrm{generation}$-y-touris $\mathrm{m} /$ market-potential

4. DCI. (2020). Post-Covid-19: Generationaldivides in travel planning. Retrieved April 29, 2021 from https://aboutdci.com/wp-content/uploads/2020/04/Generation-ReportFinal-2020.pdf

5. Deloitte. (2019). The Deloitte Global Millennial Survey 2019 - Societal discord and technologicaltransformation create a "generation disrupted". Retrieved April 28, 2021 from https://www2.deloitte.com/content/dam/Deloitte/global/Documents/Ab outDeloitte/deloitte-2019-millennial-survey.pdf

6. Donovan, N. (2021, 15th April). Novo istraživanje otkriva da putnici imaju većuželju za održivijim putovanjima [New research reveals that travellers have a greater desire for 

and Tourism Management, 2021, Vol. 9, No. 2: 79-94.

more sustainable travel]. Retrieved April 29, 2021 from https://partner.booking.com/sr/click-magazine/novo-is tra\%C5\%BEivanje-otkriva-daputnici-imaju-ve\%C4\%87u-\%C5\%BEelju-za-odr\%C5\%BEivijim-putovanjima

7. Environics Institute. (2021, March). Canadian Millennial and Gen Zsocialvalues study 2020 - Impact of the Covid-19 pandemic on Millennial and Gen Z Canadians. Retrieved May 9, 2021 from https://www.environicsinstitute.org/docs/default-source/defaultdocument-library/impact-of-the-covid-19-pandemic-on-millennial-and-genz-

canadians.pdf?Status $=$ Master\&sfvrsn=6037aa4f_3

8. ETC. (2016, May). Lifestyle trends \& tourism-How changing consumer behaviour impacts travel to Europe. Retrieved April 30, 2021 from https://etccorporate.org/uploads/reports/ETC_Lifestyle_Trends_and_Tourism.pdf

9. Euromonitor International. (2019, January 15). Euromonitor reveals the top 10 global consumer trends in 2019. Retrieved April 29, 2021 from https://www.euromonitor.com/article/euromonitor-reveals-the-top-10-global-consumertrends-in-2019

10. Euromonitor International. (2020, May). The impact of coronavirus on Millennials and Generation Z. Retrieved May 8, 2021 from https://www.euromonitor.com/the-impactof-coronavirus-on-millennials-and-generation-z/report

11. Gasdia, M., \& Jacks on, A. J. (2020, June 5). Looking to the recovery ofleisure travel demand - The road ahead is uncertain, but early demand signals create some room for $\begin{array}{lllll}\text { optimism. } & \text { Retrieved } & \text { April } & 2921 & \text { from }\end{array}$ https://www2.deloitte.com/us/en/insights/industry/retail-dis tribution/consumer-behaviortrends-state-of-the-consumer-tracker/consumer-sentiment-travel-touris m.html

12. Getz, D. (1986). Models in tourism planning: Towards integration of theory and practice. Tourism Management, 7(1), 21-32. https://doi.org/10.1016/02615177(86)90054-3

13. GlobalData. (2020, July 3). Millennial influencers will be indispensable in travel sector recovery. Retrieved April 29, 2021 from https://www.globaldata.com/millennialinfluencers-will-be-indispensable-in-travel-sector-recovery/

14. Hospitality net. (2015, December 11). Tourismmegatrends: 10 things youneed to know about the future of tourism. Retrieved April 28, 2021 from https://www.hospitalitynet.org/news/4073042.html

15. ILTM. (2020, November 2). Millennials, COVID, and the future of travel. Retrieved April 29, 2021 from https://view.iltm.com/2020/11/02/millennials -covid-and-the-futureof-travel/

16. Kalinić, Z., \& Novaković, M. (2019). Online accommodation booking habits and attitudes of Serbian travelers. Menadžment u hotelijerstvu i turizmu - Hotel and Tourism Management, 7(2), 11-23. https://doi.org/10.5937/menhottur1902011K

17. Milićević, S., \& Ervaćanin, V. (2016). Uticaj kriza na razvoj turizma u svetu [The impact of the crises on the development of tourism in the world]. Turisticko poslovanje, 18, 51-63. https://doi.org/10.5937/TurPos 1618051M

18. MSCI. (2020). Millennials - Demographic change and the impact of a generation. Retrieved April 28, 2021 from https://www.msci.com/documents/1296102/17292317/ThematicIndex-Millenials-cbren.pdf/44668168-67fd-88cd-c5f7-855993dce7c4?t=1587390986253

19. Ortiz, P. (2019). New consumer trends in tourism. Retrieved April 29, 2021 from https://www.amara-marketing.com/travel-blog/new-consumer-trends-in-tourism

20. Plog, S. C. (1974). Why destination areas rise and fall in popularity. Cornell Hotel and Restaurant Administration Quarterly, 14(4), 55-58. https://doi.org/10.1177/001088047401400409 
21. Rezdy. (2018, March 8). Millennials: An in-depth look into the travel segment [Infographic]. Retrieved April 28, 2021 from https://www.rezdy.com/blog/millennials depth-look-travel-segment-infographic/

22. Seabra, C., AlAshry, M., Çınar, K., Raja, I., Reis, M., \& Sadiq, N. (2021). Restrictions'acceptance and risk perception by young generations in a COVID-19 context. International Journal of Tourism Cities, 7(2), 463-491. https://doi.org/10.1108/IJTC-08-2020-0165.

23. Senić, R., \& Milojević, S. (2017). Poznavanje ponašanja turista: imperativ us pešne strategije marketinga u turizmu [Knowing tourists behavior: the imperative for successfulmarketing strategy in tourism]. Menadžment u hotelijerstvu i turizmu - Hotel and Tourism Management, 5(2), 61-73.

24. United Nations. (2019). 2019 Revision of worldpopulation prospects. Retrieved April 28, 2021 from https://population.un.org/wpp/ 